\title{
ANALISIS DAN PERANCANGAN ELECTRONIK CUSTOMER RELATIONSHIP MANAGEMENT PADA KLINIK XYZ
}

\author{
Joni Suhartono \\ Jurusan Teknik Informatika, Fakultas Ilmu Komputer, Bina Nusantara University \\ Jln. K. H. Syahdan No 9, Palmerah, Jakarta Barat 11480 \\ Jonis@binus.edu
}

\begin{abstract}
This research is to foster a good connection between company and customers. For customers, e-CRM will accommodate in interation and transaction with the company. This research is done because there are still weaknesses for customer's service. The research method used is literature, analysis method, and also designing method in identifying system needs then design one supporting system for the company. The research result is a CRM website that gives up-to-date information and suitable for customer needs. Therefore, CRM is hoped to help company giving a better service to customers.
\end{abstract}

Keywords: CRM, e-CRM, customer service, segmentation.

\begin{abstract}
ABSTRAK
Penelitian ini dilakukan untuk membina hubungan yang baik antara perusahaan dan pelanggan. Bagi pelanggan, e-CRM ini akan memberikan kemudahan bagi mereka dalam berinteraksi dan bertransaksi dengan perusahaan. Penelitian ini dilakukan karena melihat masih kurangnya pelayanan yang diberikan perusahaan terhadap pelanggannya. Dalam penulisan ini, metodologi yang digunakan adalah metode kepustakaan, analisis dan perancangan; yaitu dengan melakukan identifikasi kebutuhan sistem dan kemudian merancang suatu sistem pendukung pelayanan bagi perusahaan. Hasil yang dicapai adalah sebuah situs CRM yang dapat memberikan informasi yang up-to-date dan sesuai dengan kebutuhan pelanggan. Jadi e-CRM ini diharapkan dapat membantu perusahaan dalam memberikan pelayanan yang lebih baik lagi bagi para pelanggannya.
\end{abstract}

Kata kunci: CRM, loyalitas pelanggan, segmentasi. 


\section{PENDAHULUAN}

\section{Latar belakang}

Saat ini, kebutuhan informasi merupakan hal yang penting bagi kita. Penggunaan internet merupakan salah satu teknologi informasi yang memberikan dampak paling besar. Dengan internet, semua informasi dapat diperoleh dengan cepat dan biaya yang terjangkau tanpa dibatasi oleh waktu dan tempat. Berbagai kemudahan yang diberikan oleh internet menyebabkan pertumbuhan pemakai internet semakin pesat. Disamping itu dengan internet, perusahaan dapat memperkenalkan jasanya dan melakukan pelayanan secara online kepada pelanggan tanpa dibatasi oleh waktu dan tempat. Dengan demikian pangsa pasar bagi pelayanannya juga tidak dibatasi oleh waktu dan tempat.

CRM (Customer Relationship Management) merupakan suatu konsep bagaimana perusahaan memperhatikan pelanggan agar pelanggan tetap setia memakai pelayanan-pelayanannya dan juga menambah jumlah pelanggan. Kepuasan pelanggan harus ditingkatkan sehingga mereka akan terus menggunakan pelayanan perusahaan tersebut. Dengan penerapan CRM ini, perusahaan dapat member pelayanan yang tepat sasaran sesuai kebutuhan pelanggan, dimana pelanggan dapat memberikan kritik, saran dan apa saja yang dibutuhkan oleh pelanggan,

Klinik XYZ adalah salah satu perusahaan yang bergerak dibidang jasa pelayanan kesehatan. Sebagai perusahaan jasa, tentunya masalah pelayanan, kepuasan pelanggan adalah hal utama yang harus diperhatikan, karena jika pelanggan merasa tidak puas, mereka akan meninggalkan perusahaan, bahkan mereka bisa dengan cepat menyampaikan ketidakpuasan itu ke orang lain. Hal ini akan sangat merugikan perusahaan. Permasalahan yang terjadi di perusahaan ini adalah perusahaan tidak mengetahui kebutuhan atau masalah yang dihadapi pelanggan, perusahaan tidak mengetahui jadwal kunjungan pelanggan, pelanggan menginginkan membuat jadwal kunjungan secara online.

\section{Ruang Lingkup}

Ruang lingkup dalam penyusunan penulisan ini, mempunyai batasan-batasan, yaitu (1) menganalisa dan mempelajari pemasaran dan pelayanan pelanggan pada Klinik XYZ; (2) merancang sistem pemasaran melalui internet dan memudahkan pelanggan untuk melayani dirinya sendiri; dan (3) penyediaan informasi yang lengkap dan up to date mengenai perusahaan dan pelayanan-pelayanan yang diberikan kepada pelanggan.

\section{Tujuan dan Manfaat}

Tujuan dari penulisan ini adalah (1) merancang dan mengimplementasikan aplikasi CRM berbasis web, yang dapat membantu konsumen atau calon konsumen untuk mengetahui informasi tentang pelayanan yang ditawarkan pada Klinik XYZ; (2) membangun hubungan antara pihak perusahaan dengan pelanggan menggunakan media internet; (3) meningkatkan dan memperbaiki kinerja perusahaan dengan memberikan pelayanan yang terbaik kepada pelanggan.

\section{METODE}

\section{CRM (Customer Relationship Management)}

CRM adalah sebuah strategis bisnis untuk memilih dan mengatur hubungan dengan pelanggan yang paling menguntungkan. CRM memerlukan filososi dan budaya bisnis customer-centric untuk 
mendukung proses pemasaran, penjualan, dan layanan yang efektif. Aplikasi CRM dapat memungkinkan manajemen atau pengaturan hubungan baik dengan pelanggan secara efektif, dengan didukung ketersediaan kepemimpinan yang baik (Greenberg, 2002).

Menurut O’Brien (2003) CRM berfokus atas proses mendapatkan dan mempertahankan pelanggan yang berharga melalui proses pemasaran, penjualan, dan layanan. CRM menggunakan teknologi informasi untuk membuat sistem lintas fungsi perusahaan yang mengintegrasikan dan mengotomatisasi banyak proses layanan pada pelanggan dalam penjualan, pemasaran, dan layanan pelanggan yang berinteraksi dengan pelanggan perusahaan. Menurut Tunggal (2000), Customer Relationship Management (CRM) didefinisikan sebagai integrasi dari strategi penjualan, pemasaran, dan pelayanan yang terkoordinasi. Customer Relationship Management (CRM) adalah suatu jenis manajemen yangsecara khusus membahas teori mengenai penanganan hubungan antara perusahaandengan pelanggannya dengan tujuan meningkatkan nilai perusahaan di mata parapelanggannya. Customer Relationship Management (CRM) adalah sebuah sistem informasi yang terintegrasi yang digunakan untuk merencanakan, menjadwalkan, dan mengendalikan aktivitasaktivitas prapenjualan dan pascapenjualan dalam sebuah organisasi.

\section{Tujuan Customer Relationship Management}

Menurut Kalakota \& Robinson (2001) tujuan dari kerangka bisnis CRM adalah (1) menambah hubungan yang telah ada untuk menambah pendapatan, perusahaan memandang pelanggan secara luas untuk memaksimalkan hubungan diantara mereka sehingga dapat meningkatkan profibilitas perusahaan dengan mengidentifikasi, menarik, dan mempertahankan pelanggan potensial; (2) menggunakan informasi yang terintegrasi untuk pelayanan yang terbaik, dengan menggunakan informasi pelanggan untuk memberikan pelayanan yang lebih baik bagi kebutuhannya, maka pelanggan tidak perlu berulang kali meminta informasi yang mereka butuhkan kepada perusahaan sehingga menghemat waktu dan mengurangi frustasi mereka; (3) memperkenalkan saluran proses dan prosedur yang konsisten dan dapat ditiru, dengan perkembangan saluran komunikasi bagi pelanggan, maka semakin banyak karyawan yang terlibat dalam transaksi penjualan, sehingga perusahaan harus memperbaiki konsistensi proses dan prosedurat. Jadi tujuan dari CRM adalah untuk memperoleh hubungan dengan pelanggan yang dapat memberikan keuntungan yang signifikan bagi perusahaan. Untuk mencapai tujuan tersebut, bagian pemasaran, penjualan dan pelayanan pelanggan harus bekerjasama lebih erat dalam sebuah teamwork dan saling berbagi informasi.

\section{Tahapan Customer Relationship Management (CRM)}

Beberapa tahap CRM, berdasarkan Strauss (2001), yaitu:

\section{Mengidentifikasi Customer}

Informasi adalah penggerak CRM. Perusahaan mendapatkan informasi mengenai individual customer dari berbagai sumber (personal maupun automated) seperti force, customer service encounter, bar code scanners dan website. Semakin banyak informasi yang dimiliki perusahaan, semakin baik nilai yang bisa disediakan bagi setiap customer dan calon customer dalam hal keakuratan, ketepatan waktu dan dapat memberikan penawaran yang masuk akal.

\section{Membedakan Customer}

Customer memiliki kebutuhan yang berbeda. Internet memungkinkan perusahaan untuk mengumpulkan informasi untuk mengidentifikasikan berbagai kesamaan maupun perbedaan individu dan kelompok, kemudian menggukannya untuk meningkatkan keuntungan. 
CRM memungkinkan perusahaan untuk menggunakan sumber daya yang ada dan menerapkannya secara tidak sama terhadap customer yang paling menguntungkan. Ide yang baru ialah bahwa teknologi memungkinkan perusahaan untuk mengidentifikasi high-value customer sehingga bisa memberikan penawaran secara real-time.

\section{Menyesuaikan Marketing}

Bila perusahaan telah mengidentifikasi dan membedakan customer berdasarkan karakteristik, behavior, kebutuhan atau nilai, perusahaan kemudian bisa menyesuaikan penawaran terhadap berbagai segmen atau individu. Interaksi dengan customer adalah suatu yang memungkinkan perusahaan untuk mengumpulkan data yang dibutuhkan untuk mengidentifikasi dan membedakan, serta untuk mengevaluasi keefektifan hasil penyesuaian marketing (Strauss, 2001).

\section{Kerangka CRM}

Dari titik pandang arsitektur, kerangka CRM secara keseluruhan dapat diklasifikasikan kedalam tiga komponen utama yaitu (1) collaborative CRM, merupakan seperangkat aplikasi dari pelayanan seperti email, ecommunities, world wide web, publikasi personal, dan alat sejenisnya yang dirancang untuk memfasilitasi interaksi antara pelanggan dengan perusahaan; (2) operational CRM, merupakan pengelolaan secara otomatisasi dari proses bisnis terintegrasi, termasuk customer touch point dan integrasi front back office; (3) analytical CRM, merupakan analisis data yang diperoleh dari oprasional CRM dengan memanfaatkan tool dan software untuk mendapatkan pemahaman yang lebih baik tentang perilaku pelanggan.

\section{Aplikasi CRM}

Menurut O’Brien (2003), sistem CRM meliputi sekelompok modul software yang memberi berbagai alat, yang membantu perusahaan dan para karyawannya memberikan layanan yang cepat, dapat diandalkan, dan konsisten ke para pelanggannya. Aplikasi utama dalam CRM adalah:

\section{Manajemen Kontrak dan Rekening}

Software CRM membantu para praktisi penjualan, pemasaran, dan layanan untuk menangkap serta menelusuri data yang relevan mengenai setiap kontrak yang sudah lewat atau yang direncanakan dengan para pelanggan atau calon pelanggan. Sistem CRM menyimpan data tersebut dalam database umum untuk pelanggan yang mengintegrasikan semua informasi rekening pelanggan serta membuatnya tersedia di seluruh perusahaan melalui Internet, intranet, atau hubungan jaringan lainnya untuk aplikasi penjualan, pemasaran, layanan, dan aplikasi CRM lainnya.

\section{Penjualan}

Sistem CRM memberikan para staff penjualan software dan sumber data perusahaan yang mereka butuhkan untuk mendukung serta mengelola aktivitas penjualan mereka, dan mengoptimalkan penjualan silang dan peningkatan tawaran untuk penjualan. CRM juga memberi mereka akses realtime ke suatu tampilan umum atas pelanggan, hingga memungkinkan mereka untuk memeriksa semua aspek dari status rekening pelanggan dan sejarahnya, sebelum menjadwalkan panggilan telepon untuk penjualan mereka.

\section{Pemasaran dan Pemenuhan Pesanan}

Software CRM akan membantu para praktisi pemasaran untuk menangkap dan mengelola data respons pelanggan dan calon pelanggan di database CRM, serta menganalisis nilai pelanggan dan nilai 
bisnis dari kampanye pemasaran langsung perusahaan. CRM juga membantu dalam pemenuhan respons calon pelanggan serta pelanggan dengan secara cepat menjadwalkan kontak penjualan serta memberi informasi yang tepat atas produk dan jasa bagi mereka, sementara sambil menangkap informasi yang relevan untuk database CRM.

\section{Layanan dan Dukungan untuk Pelanggan}

Sistem CRM memberi para staff penjualan alat software dan akses real-time ke database umum pelanggan yang dapat dibagi bersama dengan para praktisi penjualan dan pemasaran. CRM membantu para manajer layanan pelanggan membuat, menetapkan, dan mengelola berbagai permintaan atas layanan dari pelanggan.

\section{Peralatan E-CRM}

Menurut Turban (2002), alat-alat yang digunakan untuk mendukung e-CRM yaitu (1) personalized web page, yaitu halaman web dapat digunakan untuk mencatat pembelian dan preferensi customer; (2) tracking tools, adalah tool yang digunakan oleh customer untuk mengetahui pemesanan yang telah dilakukan sehingga menghemat waktu dan biaya perusahaan; (3) e-mail dan automated response, digunakan untuk mengirimkan informasi, konfirmasi dan membangun korespondensi dengan customer; (4) help desk atau call center, help desk atau call center berfungsi sebagai customer sevice yang biasanya menggunakan fasilitas telepon, faksimili, atau e-mail.

\section{PEMBAHASAN}

Seperti telah dibahas pada bab sebelumnya mengenai permasalahan yang dihadapi oleh Klinik XYZ, di mana Klinik XYZ ingin membuat alternatif cara bagi para pelanggannya yang dalam melakukan janji dan berkonsultasi dengan dokternya secara online, oleh karena itu maka dibuatkanlah sistem CRM. Di sini penulis ingin menjelaskan apakah itu CRM dan apakah peranannya bagi Klinik XYZ sehingga dikatakan dapat mempertahankan dan meningkatkan jumlah pelanggan secara signifikan.

Sebuah usaha di bidang jasa juga pun tidak akan berjalan jika tidak adanya pelanggan yang memakai jasa mereka sehingga sama seperti usaha di bidang produk, akan mati karena tidak adanya pemasukan dari pemakaian jasa. Pelanggan merupakan faktor paling utama dalam dunia usaha, tanpa adanya pelanggan maka usaha itu tidak jalan. Sebuah usaha di bidang produk tidak akan berjalan jika tidak adanya pelanggan yang membeli produk mereka, produk-produk akan tersimpan menjadi stok di gudang mereka, dan akhirnya usaha mereka akan mati karena tidak adanya pemasukan dari penjualan. Oleh karena itu muncullah ungkapan bahwa pelanggan adalah raja, karena memang pelanggan adalah yang segala-galanya dalam dunia usaha.

Pelanggan yang sudah ada harus terus dipertahankan serta dibina sebaik mungkin sehingga tercipta suatu kepercayaan pelanggan terhadap perusahaan yang akan membuatnya terus memakai produk atau jasa dari perusahaan tersebut walau apapun produk atau jasa yang ditawarkan oleh pesain perusahaan tersebut. Selain pelanggan-pelanggan lama yang setia, pelanggan-pelanggan yang baru pun harus tetap dicari secara konsisten.

Pencarian pelanggan-pelanggan baru ini dapat dilakukan dengan mencari pelangganpelanggan baru tersebut ke lapangan, dengan membuat iklan atau promosi dan juga mendatangi pelanggan dari pintu ke pintu. Namun yang paling penting dalam mendapatkan kepercayaan pelanggan-pelanggan baru bukanlah cara-cara seperti itu, melainkan dengan cara Ad Lips, yaitu 
pengiklanan usaha kita dari mulut ke mulut. Di sinilah pelanggan-pelanggan lama dapat kita manfaatkan dalam mencapai tujuan itu. Mereka yang sudah loyal atau setia terhadap perusahaan pada umumnya akan memiliki kebiasaan untuk membicarakan perusahaan tersebut kepada teman dan kerabatnya, proses pemasaran pun sudah terjadi secara tidak langsung, dan inilah cara pemasaran atau promosi yang paling efektif karena dikeluarkan oleh teman atau kerabat mereka yang mereka percayai. Sehingga dengan berbekal kepercayaan mereka, pelanggan-pelanggan baru tersebut, kepada teman atau kerabatnya yang menceritakan perusahaan tersebut, secara tidak langsung benih-benih kepercayaan terhadap perusahaan sudah mulai tertanam. Hal-hal seperti inilah yang harus kita pertahankan, terus eksplorasi dan terus diperbesar ruangnya.

Namun, perlu diperhatikan bahwa hal ini bagaikan pedang bermata dua, kalau hubungan kita dengan pelanggan-pelanggan lama tersebut tidak terbina dengan baik, maka hal sebaliknyalah yang akan terjadi, pelanggan-pelanggan lama tersebut akan berpotensi menyebarkan kabar-kabar miring terhadap perusahaan sehingga memberikan image yang buruk bagi perusahaan, hal ini tentunya akan menjadikan perusahaan kesulitan dalam mendapatkan kepercayaan pelanggan-pelanggan baru. Oleh karena itu, maka pembinaan hubungan antara perusahaan dengan pelanggan yang baik.

\section{Peranan CRM Pada Klinik XYZ}

Kesuksesan CRM dapat diukur melalui tujuan tujuan akhir dari CRM itu sendiri, yaitu meningkatnya pendapatan. Apakah dengan diterapkannya CRM pada Klinik XYZ akan berpengaruh pada tingak pendapatan yang meningkat atau kah sebaliknya inilah yang nantinya akan menjadi nilai tolak ukur bagi kesuksesan penerapan CRM di Klinik XYZ. Disini CRM harus benar-benar dapat berperan sebagai moda alternatif utama bagi para pelanggan untuk menjangkau Klinik XYZ, sehingga didalamnya harus memiliki fungsi-fungsi yang mendukung hal tersebut. Peningkatan pendapatan bagi Klinik XYZ dengan diterapkannya CRM ini dapat dilihat dari dua sisi peranannya, yaitu sisi pelanggan dan sisi perusahaan.

\section{Sisi Pelanggan}

Seperti telah disampaikan oleh penulis bahwa CRM Klinik XYZ hanya mendukung layanan klinik dan laboratorium saja. CRM ini memiliki beberapa fitur yang memudahkan pelanggan dalam hal membuat janji untuk melakukan kunjungan, berkonsultasi dengan dokter, mendata dan melihat histori atau rekap data laboratoriumnya. Disini penulis akan membahas satu per satu setiap peranan yang ada di CRM Klinik XYZ ini.

\section{Pendaftaran Pelanggan}

Pendaftaran pelanggan dibedakan menjadi dua tipe pada CRM ini atas beberapa alasan apabila dilihat dari sisi pelanggan dan sisi perusahaan. Dari sisi pelanggan, hal ini tentunya bertujuan untuk memudahkan pendaftaran bagi pelanggan yang memang sudah terdaftar di Klinik XYZ sebagai pelanggan. Karena pada saat pertama kali melakukan pendaftaran di lokasi, informasi pelanggan tersebut akan disimpan ke dalam database Klinik XYZ yang berhubungan dengan CRM Klinik XYZ, sehingga sewaktu pelanggan baru tipe ini melakukan pendaftaran pada CRM Klinik XYZ, mereka hanya perlu memasukkan nomor pelanggan, username dan juga password. Informasi lainnya terkait data pribadi dan data laboratorium (jika sudah pernah terdata) akan secara otomatis ditarik datanya oleh CRM Klinik XYZ dari ERP Klinik XYZ. Sedangkan untuk pelanggan baru tipe kedua, yaitu tipe non-member, mereka masih harus memasukkan alamat email mereka untuk otorisasi dan tentunya data pribadi serta data laboratorium pelanggan baru tipe ini tidak akan ada isinya karena memang belum terdata, sehingga mereka perlu memasukkan informasi mereka secara manual. 


\section{Janji Kunjungan}

Pelanggan dapat membuat janji kunjungan dengan dokter yang diinginkan dan di lokasi klinik yang diinginkan. Dengan fasilitas ini, pelanggan yang ingin melakukan kunjungan dapat menentukan jam kunjungan, ingin dilayani oleh dokter siapa sehingga ketika mereka sudah tiba di Klinik, pelanggan sudah tidak perlu menunggu terlalu lama untuk dilayani karena mereka sudah melakukan janji kunjungan.

\section{Konsultasi}

Fasilitas ini disediakan agar pelanggan yang ingin bertanya atau berkonsultasi ringan, bisa dilayani dengan baik. Di sini pelanggan dapat melakukan pertanyaan atau keluhan singkat kepada dokter yang diinginkan dan nantinya akan mendapat jawaban atas pertanyaan atau keluhan tersebut oleh dokter yang bersangkutan. Fitur ini akan sangat membantu bagi para pelanggan yang ingin mendapatkan jawaban cepat dan singkat dari dokter langganannya sebelum mereka pergi berkonsultasi ke lokasi.

Dalam menjaga depedensi pelanggan terhadap Klinik XYZ, dalam hal ini supaya tidak melakukan konsultasi dengan dokter di luar sepengetahuan Klinik XYZ, maka setiap konsultasi yang masuk dan keluar di CRM ini akan ditembuskan kepada kepala dokter Klinik XYZ sehingga hal-hal tidak diinginkan seperti disebutkan tadi dapat diminimalisir tanpa mengurangi kenyamanan dan kemudahan fasilitas yang diberikan kepada pelanggan.

\section{Data Laboratorium}

Pada data laboratorium ini informasi laboratorium pelanggan akan disimpan baik itu hasil laboratorium yang dilakukan di laboratorium Klinik XYZ atau di laboratorium lain. Apabila pemeriksaan laboratorium dilakukan oleh pelanggan di laboratorium Klinik XYZ, maka data-data laboratorium pelanggan tersebut akan di-up-date oleh pihak Klinik XYZ setelah hasil pemeriksaan keluar dan dapat segera dilihat di CRM oleh pelanggan. Namun apabila pemeriksaan laboratorium dilakukan oleh pelanggan di luar laboratorium Klinik XYZ, data-data laboratorium tersebut dapat juga disimpan oleh pelanggan melalui fitur data laboratorium ini. Data-data laboratorium yang disimpan pada fitur ini terbagi atas lima substansi kategori utama, yaitu sindrom metabolik, profil lipid, fungsi ginjal, fungsi hati, dan yang terakhir dikelompokkan ke dalam lainnya. Penggambaran data-data yang disimpan di fitur ini, yaitu sindrom metabolik, profil lipid, fungsi ginjal, fungsi hati, dan lainnya.

\section{Histori Laboratorium}

Pada fitur histori laboratorium akan ditampilkan histori laboratorium pelanggan bersangkutan yang ditampilkan berdasarkan waktu per hari per perubahan atau data baru. Maksudnya adalah, apabila dalam suatu hari tidak adanya perubahan atau data baru, maka hari tersebut tidak akan ditampilkan karena memang tidak memiliki data baru. Namun apabila dalam satu hari yang sama dilakukan perubahan melebihi satu kali, maka hanya data terakhirlah yang akan ditampilkan oleh histori laboratorium karena dianggap data yang paling teraktual pada hari itu.

Data-data laboratorium yang disajikan dalam laporan histori laboratorium ini pun tidak semuanya ditampilkan, hanya tujuh data saja yang dianggap penting dikarenakan seringnya terjadi perubahan yang cukup signifikan dan inkonsisten. Data-data tersebut adalah tekanan darah (sistol dan diastol), gula darah, HDL, LDL, lipid dan trigliserida. Penyajian laporan histori laboratorium diberikan dalam dua bentuk, yang pertama adalah bentuk grafis berupa line-chart yang menampilkan ketujuh data seperti disebut di atas dengan warna-warna yang berbeda sehingga mudah untuk dibaca 
dan dipahami. Sedangkan yang kedua adalah dalam bentuk tabel yang menampilkan data-data tersebut dengan menggunakan tabel.

\section{Data Pribadi}

Pada fitur data pribadi, pelanggan dapat mendata informasi mengenai pelanggan tersebut untuk keperluan komunikasi antara Klinik XYZ dengan pelanggan. Fitur ini hanyalah sebuah fitur yang optional bagi pelanggan, namun menjadi sebuah fitur yang mandatori bagi Klinik XYZ yang nantinya akan penulis bahas pada bagian peranan CRM pada sisi perusahaan.

\section{Sisi Perusahaan}

Dari sisi perusahaan, data pribadi pelanggan merupakan hal penting bagi perusahaan, dimana perusahaan dapat dengan mudah menghubungi pelanggan apabila terdapat promosi-promosi baru. Dan tentunya dengan mengamati hasil laporan laboratorium, Klinik XYZ dapat memantau kondisi pelanggannya.

\section{Segmentasi Pelanggan}

Data hasil laboratorium pelanggannya, dapat digunanak untuk memantau segmentasi terhadap pelanggannya dengan beberapa kondisi.Misalnya pelanggan yang memiliki tekanan darah tinggi, atau yang memiliki kadar asam urat yang tinggi. Dengan begitu, apabila Klinik XYZ memiliki promosi yang berhubungan dengan tekanan darah, Klinik XYZ dapat langsung memberikan promosi tersebut pada pelanggan yang memang dikiranya benar-benar membutuhkan informasi tersebut.

Dengan adanya segmentasi pelanggan maka segala aktivitas promosi dapat lebih tepat pada sasaran dan tentunya ini juga berhubungan dengan peningkatan pendapatan serta dapat meminimalisir biaya yang dikeluarkan. Contoh pemborosan biaya apabila tidak dilakukan segmentasi pelanggan misalnya adalah dengan memberikan promosi secara menyeluruh kepada semua pelanggan yang tentunya akan memakan biaya. Namun dengan adanya segmentasi pelanggan, seperti dikatakan di atas, promosi dapat dilakukan lebih tepat sasaran, maksudnya adalah hanya yang memerlukan yang akan diprioritaskan untuk diberikan promosi.

\section{Notifikasi Pelanggan}

Dengan fasilitas Notifikasi Pelanggan ini, perusahaan dapat selalu memantau maupun mengingatkan pelanggan terhadap jadwal kesehatan mereka. Sebagai contoh, perusahaan mengingatkan ke pelanggan untuk jadwal kunjungannya, untuk jadwal pemeriksaan laboraturium, ataupun yang lainnya. Dengan adanya Nofikasi Pelanggan, maka pelanggan merasa sangat diperhatikan sehingga dapat menciptakan loyalitas terhadap perusahaan.

\section{SIMPULAN}

Berdasarkan hasil analisis di atas, dapat disimpulkan bahwa penerapan CRM memberi jalur komunikasi dua arah antara perusahaan dengan pelanggannya dalam menciptakan sebuah tingkat kepuasan dan kepercayaan bagi pelanggan terhadap perusahaan dan di sisi perusahaan mendapatkan solusi dalam memberikan pelayanan yang seharusnya kepada pelanggan yang tepat dengan karakteristik pelanggan yang berbeda-beda (segmentasi pelanggan). Perusahaan dapat lebih mengenal pelanggannya secara detil sehingga pelayanan mereka bias lebih terarah berdasarkan history kesehatan masing masing pelanggan. Perusahaan dapat mengingatkan jadwal kunjungan pelanggan, jadwal periksa laboratorium. 


\section{DAFTAR PUSTAKA}

Greenberg, P. (2002). CRM capturing and keeping customer in internet real time. (2nd ed.). California: McGraw-Hill.

Kalakota, R., \& Robinson, M. (2001). E-Bussiness 2.0 : Roadmap For Success. Canada: AddisonWasley Pearson Education.

O’Brien, J. A. (2003). Pengantar Sistem Informasi: Perspektif Bisnis dan Manajerial, (12th ed.). Jakarta: Salemba Empat.

Strauss, J., El-Ansary, A., \& Frost, R. (2003). E-marketing. (3rd ed.). Pearson Education.

Tunggal, A. W. (2000). Konsep Dasar Customer Relationship Management. Jakarta: Harvarindo.

Turban, E., King, D., Lee, R., \& Viehland, D. (2004). Electronic Commerce: A Managerial Perspective. New Jersey: Prentice Hall. 